\title{
Influence of follicular maturation on 3-hydroxy-methylglutaryl coenzyme A reductase activity in hen granulosa cells*
}

\author{
E. K. Asem and F. Hertelendy \\ Departments of Obstetrics and Gynecology and of Physiology, St Louis University \\ School of Medicine, St Louis, Missouri 63104, U.S.A.
}

\begin{abstract}
Summary. The activity of 3-hydroxy-3-methylglutaryl coenzyme A reductase (HMG-CoA reductase: EC 1.1.1.34) was measured in a microsomal preparation of the granulosa of rapidly growing ovarian follicles of laying hens in the late preovulatory period (2-3 h before expected ovulation). The specific activity of the enzyme was measured in the five largest $\left(\mathrm{F}_{1}-\mathrm{F}_{5}\right)$ preovulatory follicles, $\mathrm{F}_{1}$ being the follicle destined to ovulate first. Enzyme activity increased concomitantly with follicle size. The apparent $K_{\mathrm{m}}$ of the enzyme decreased $60-80 \%$ from the smallest to the largest preovulatory follicle. There was no significant change in the $V_{\max }$ during follicle development. Although our results have demonstrated the presence of $\mathrm{HMG} / \mathrm{CoA}$ reductase in chicken granulosa cells and the progressive increase of its activity with follicular maturation, the quantitative significance of de-novo synthesized cholesterol as steroid hormone precursor remains to be ascertained.
\end{abstract}

\section{Introduction}

The importance of 3-hydroxy-3-methylglutaryl coenzyme A reductase (HMG-CoA reductase: EC 1.1.1.34), the rate-limiting enzyme in cholesterol biosynthesis (Beg \& Brewer, 1981), has been examined in relation to ovarian steroidogenesis in several mammalian species (reviewed by Gwynne \& Strauss, 1982). Cholesterol, the common precursor of all steroid hormones, is made available in steroidogenic cells from (a) de-novo synthesis, (b) lipoprotein-carried cholesterol from the circulation, and (c) intracellular stored cholesterol.

Several studies performed under in-vivo conditions have demonstrated that the steroidogenic cholesterol substrate of adrenals, corpus luteum, placenta and ovary of humans (Borkowski et al., 1967; Hellig et al., 1970), rats (Major et al., 1967) and dogs (Krum et al., 1964) originates from extracellular sources. However, rat and hamster Leydig cells, hamster adrenal gland and Leydig tumour cells preferentially utilize endogenously synthesized cholesterol as the primary substrate for steroidogenesis (Morris \& Chaikoff, 1959; Lehoux \& Lefebvre, 1980). Silavin \& Strauss (1983) have reported that hamster granulosa cells depend solely on prestored endogenous cholesterol for acutely stimulated steroidogenesis, emphasizing the fact that different steroidogenic tissues from different species may depend on different sources of cholesterol for steroid hormone biosynthesis. Avian granulosa cells, particularly those isolated from the mature follicle of laying hens, produce copious amounts of progesterone in response to $\mathrm{LH}$ and other agonists during short-term incubations (Asem \& Hertelendy, 1985). However, the steroidogenic response of granulosa cells harvested from younger, developing follicles to $\mathrm{LH}$ or to nonreceptor-mediated agonists such as forskolin and cyclic AMP analogues is greatly reduced (Asem \& Hertelendy, 1985). It therefore

* Reprint requests to Dr F. Hertelendy. 
appears that the steps responsible for the differential steroidogenic ability of mature and developing avian granulosa cells obtained in the late preovulatory period are distal to cyclic AMP generation, with the cholesterol side-chain cleavage enzyme step as one of the main control points. Other regulatory steps may impinge on cholesterol synthesis and/or storage, release and transportation to the mitochondrial side-chain cleavage enzyme site.

In the present studies, we measured the activity of HMG-CoA reductase, the key enzyme in cholesterol biosynthesis, in the granulosa cell layer of the chicken and correlated it with follicle size.

\section{Materials and Methods}

Hormones and chemicals. DL-3-Hydroxy-3-methylglutaryl CoA (HMG-CoA), DL-mevalonic acid lactone, glucose- 6 phosphate dehydrogenase, nicotinamide adenine dinucleotide phosphate (NADP ${ }^{+}$), glucose- 6 phosphate and sucrose were purchased from Sigma Chemical Co. (St Louis, MO). Silica gel GHL thin-layer plates were obtained from Analtech (Newark, DE). Radiolabelled compounds DL-3-[glutaryl-3- ${ }^{14} \mathrm{C}$ ]hydroxy-3-methylglutaryl coenzyme A (sp. act. $47.2 \mathrm{mCi} / \mathrm{mmol}$ ), $R S-\left[5-{ }^{3} \mathrm{H}(\mathrm{N})\right]$ mevalonolactone (sp. act. $24 \cdot 0 \mathrm{Ci} / \mathrm{mmol}$ ), and $\left[1,2,6,7-{ }^{3} \mathrm{H}\right]$ progesterone $(\mathrm{sp}$. act. $90 \cdot 1 \mathrm{Ci} / \mathrm{mmol}$ ) were purchased from New England Nuclear (Boston, MA). Compactin (ML-263B) was obtained through the courtesy of Dr A. Endo, Tokyo Noko University, Tokyo, Japan, and of Dr J. F. Strauss III, University of Pennsylvania, Philadelphia, PA.

Experimental animals. White Leghorn hens in their first year of egg laying were caged individually, in a windowless air-conditioned room with lights on from 06:00 to 20:00 h. The birds had free access to a pelleted commercial laying ration (Purina Layena) and tap water. The time of oviposition was monitored by an electronic device (Hammond $e t$ al., 1980) and birds with at least 6 consecutive laying days were selected for experiments.

All animals used in this study were killed 2-3 h before ovulation of the largest follicle. During this period of the ovulatory cycle, granulosa cells are very sensitive to hormonal stimulation (Hertelendy \& Asem, 1984).

Preparation of tissue. Granulosa tissue obtained as described by Asem \& Hertelendy (1985) was homogenized in 5 volumes of $20 \mathrm{~mm}$-potassium phosphate buffer, pH 7.4, containing $200 \mathrm{~mm}$-potassium chloride, $5 \mathrm{~mm}$-EDTA, $0.2 \mathrm{M}$-sucrose and $5 \mathrm{~mm}$-dithiothreitol (homogenizing buffer), in an all-glass dounce homogenizer. The homogenate was centrifuged at $600 \mathrm{~g}$ for $60 \mathrm{~min}$ and the resulting supernatant fraction was then centrifuged at $100000 \mathrm{~g}$ for $60 \mathrm{~min}$ to sediment microsomes. The microsomes were washed once in homogenizing buffer before resuspension in assay buffer.

Enzyme assay. The HMG-CoA reductase activity was measured by the radiochemical assay described by Balasubramanian et al. (1977), with slight modifications. Briefly, the microsomes were resuspended in assay buffer containing $100 \mathrm{~mm}$-potassium phosphate, $\mathrm{pH} \mathrm{7.4,5} \mathrm{mm}$-EDTA and $5 \mathrm{~mm}$-dithiothreitol. The final mixture contained $2.5 \mathrm{~mm}$-NADP ${ }^{+}, 20 \mathrm{~mm}$-glucose- 6 phosphate, 1 unit of glucose- 6 phosphate dehydrogenase, and appropriate aliquants of microsomal protein. Final incubation volume was $200 \mu 1$. Tubes were preincubated for $10 \mathrm{~min}$ at $37^{\circ} \mathrm{C}$, after which the reaction was initiated by the addition of DL-3-[glutaryl-3- ${ }^{14}$ C]hydroxy-3-methylglutaryl coenzyme $\mathrm{A}$ ( 20000 d.p.m./nmol). The reaction was allowed to continue for an additional $8 \mathrm{~min}$ at $37^{\circ} \mathrm{C}$, after which it was terminated with $20 \mu \mathrm{l} 5 \mathrm{~N}-\mathrm{HCl}$ containing $\left[5-{ }^{3} \mathrm{H}\right]$ mevalonic acid $\left(10^{5} \mathrm{~d} . \mathrm{p} . \mathrm{m} . / \mu \mathrm{mol}\right)$ to monitor recovery of the product. The tubes were incubated for an additional $30 \mathrm{~min}$ at $37^{\circ} \mathrm{C}$ to ensure lactonization of $\left[{ }^{14} \mathrm{C}\right] \mathrm{mevalonic}$ acid. Blank tubes were treated identically except that stopping solution was added before incubation.

The resulting $\left[{ }^{14} \mathrm{C}\right]$ mevalonolactone product was extracted twice with 40 volumes of diethyl ether. The ether phase was dried under nitrogen and the product was separated by thin-layer chromatography in a solvent system of toluene: acetone:acetic acid (20:10:1; by vol.). The silica gel was scraped from the plates in 1-cm strips and the radioactivity in every strip was measured in a Beckman liquid scintillation spectrophotometer (Model LS 7000) in a toluene:triton $(2: 1 ; \mathrm{v} / \mathrm{v})$ scintillation cocktail. The radioactivity corresponding to an authentic mevalonolactone spot $\left(R_{\mathrm{f}} 0.6-0.8\right)$ was used in calculating the amount of mevalonic acid formed.

Recovery of product averaged $65-75 \%$ and values reported have been corrected accordingly. The enzyme assay conditions were selected such that the product formation was linear with time and protein concentration. Results are expressed as nmol mevalonate $/ \mathrm{mg}$ protein $/ \mathrm{min}$.

Protein content was measured by the method of Bradford (1976) using BSA as standard.

Data analysis. Data were tested for statistical significance by analysis of variance and post-hoc Tukey's test. Student's $t$ test was used when applicable.

\section{Results}

The activity of HMG-CoA reductase increased concomitantly with follicular maturation (Fig. 1). Its activity increased 4-6-fold from the $F_{5}$ to the $F_{1}$ follicle. Using increasing substrate concentrations, typical hyperbolic saturation curves were obtained (Fig. 2). Double-reciprocal plots of the 


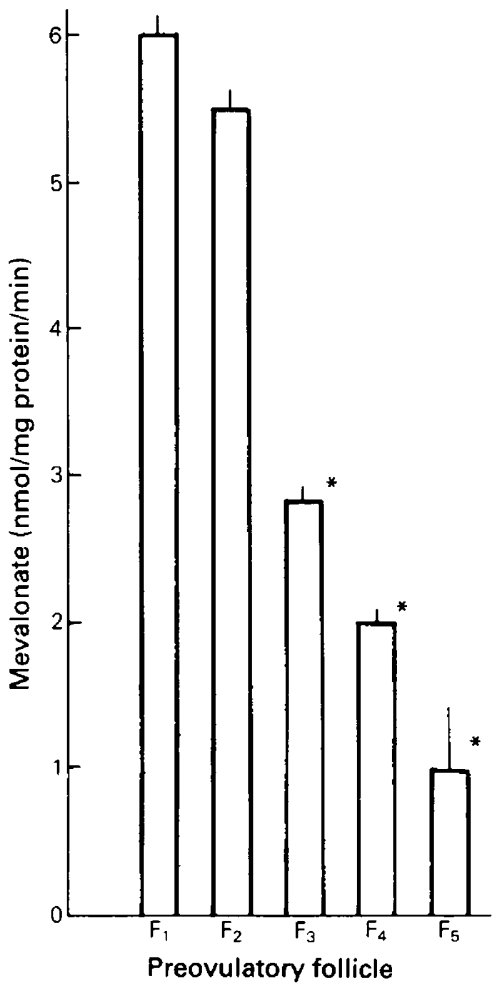

Fig. 1. Effect of follicle size on HMG-CoA reductase activity. Microsomes isolated from granulosa membranes obtained from the five largest preovulatory follicles $\left(F_{1}-F_{5}\right) 2-3 \mathrm{~h}$ before expected ovulation were incubated with $10 \mu \mathrm{M}-\mathrm{HMG}-\mathrm{CoA}$. Protein concentration was 7-9 $\mu \mathrm{g} /$ tube. All other conditions were as described in 'Materials and Methods'. Results are mean \pm s.e.m. of 4 separate experiments each performed in triplicate. ${ }^{*} P<0.05$ compared with value for $F_{1}$ follicle.

data indicated that there was a significant change in the apparent $K_{\mathrm{m}}$ of the enzyme as the follicle approached ovulation (Fig. 3). To obtain the apparent kinetic parameters $\left(K_{\mathrm{m}}\right.$ and $\left.V_{\max }\right)$ the data were subjected to analysis by Hofstee's method (1952) and a linear regression programme was used to calculate the slope (the negative value of apparent $K_{\mathrm{m}}$ ) and the $y$-intercept (the apparent $V_{\max }$ ). Table 1 shows that the apparent $K_{\mathrm{m}}$ decreased $80 \%$ during follicular development from the $\mathrm{F}_{4}$ to the $\mathrm{F}_{1}$ follicle $(65 \mu \mathrm{M}$ and $10 \mu \mathrm{M})$, whereas the corresponding $V_{\max }$ values increased only $1 \cdot 5$-fold.

The amount of mevalonate (product) formed by microsomes in our incubations was directly proportional to the quantity of the microsomal protein up to $10 \mu \mathrm{g}$. For $F_{1}$ cells, mevalonate formed by $1,3,6$ and $10 \mu \mathrm{g}$ microsomal protein was $14.6 \pm 1 \cdot 4,27 \cdot 0 \pm 6 \cdot 1,36.6 \pm 2.6$ and $42.0 \pm 1.0 \mathrm{nmol} / \mathrm{min}$ respectively. When microsomes were isolated from $F_{3}$ cells, product formation by similar amounts of protein was $8.75 \pm 0.2,11.5 \pm 0.9,21.9 \pm 1.0$ and $26.5 \pm 2.0 \mathrm{nmol} / \mathrm{min}$ respectively. The product formation progressed at an approximately linear rate up to $12 \mathrm{~min}$ for $\mathrm{F}_{1}$ and 20 min for $F_{3}$ follicles (Fig. 4), manifesting once again the distinct difference in enzyme activity between mature and developing follicles.

Compactin, a specific inhibitor of HMG-CoA reductase (Endo et al., 1977), inhibited the enzyme activity such that $12.5 \mu \mathrm{M}$ and $25 \mu \mathrm{M}$ compactin suppressed the enzyme activity from $5.9 \pm 0.8 \mathrm{nmol} / \mathrm{mg}$ protein $/ \mathrm{min}$ to $0.4 \pm 0.001$ and $0.32 \pm 0.02 \mathrm{nmol} / \mathrm{mg}$ protein $/ \mathrm{min}$ respectively ( $n=6$ observations). 


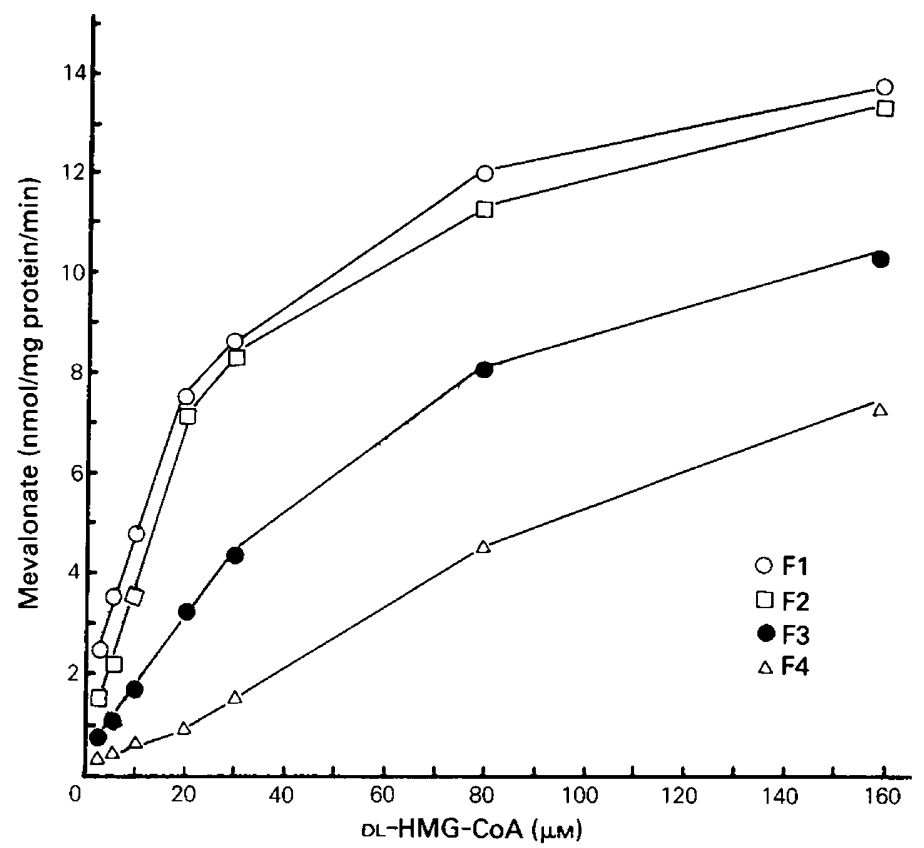

Fig. 2. Influence of follicular maturation of HMG-CoA reductase activity. Microsomes, isolated from granulosa membranes obtained from the 4 largest preovulatory follicles $\left(F_{1}-F_{4}\right)$ 2-3 $\mathrm{h}$ before expected ovulation, were assayed for enzyme activity in the presence of increasing concentrations of HMG-CoA substrate. Protein concentration was $7 \mu \mathrm{g} /$ reaction tube. Results are mean \pm s.e.m. of triplicate observations. The vertical bars representing s.e.m. are not shown because these were smaller than the size of the symbols. The experiment was repeated once more with similar results. The $F_{3}$ and $F_{4}$ curves are significantly different from the $F_{1}$ curve $(P<0.05)$.

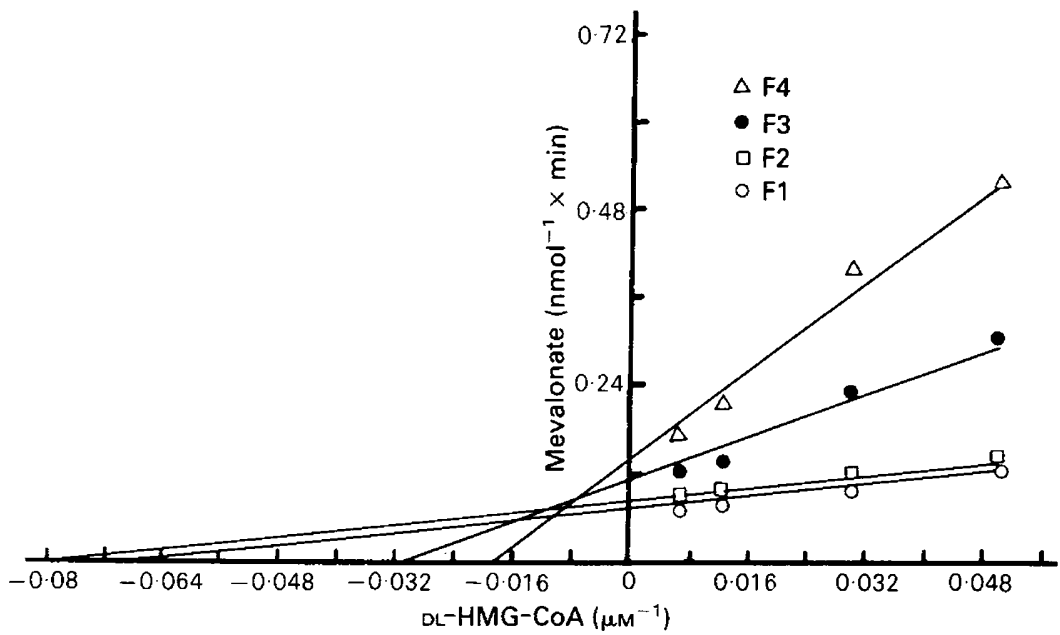

Fig. 3. Lineweaver-Burk plots of the HMG-CoA reductase activity. The values shown in Fig. 2 are presented in a double reciprocal plot. The straight lines were calculated using linear regression analysis. All four lines had correlation coefficients $>0.9$. 
Table 1. Effect of follicular maturation on the kinetic parameters of HMG-CoA reductase activity

\begin{tabular}{lcccc}
\hline Follicle & $\begin{array}{c}K_{\mathrm{m}} \\
(\mu \mathrm{M})\end{array}$ & $\begin{array}{c}V_{\max } \\
\left(\mathrm{nmol.min} \mathbf{m}^{-1}\right. \\
\text { mg protein }\end{array}$ & $\begin{array}{c}\text { Correlation } \\
\text { coefficient }\end{array}$ & $\begin{array}{c}\text { Regression } \\
\text { equation }\end{array}$ \\
\hline $\mathrm{F}_{1}$ & $15 \cdot 0$ & $13 \cdot 2$ & 0.95 & $y=13 \cdot 2-15 \cdot 0 x$ \\
$\mathrm{~F}_{2}$ & $20 \cdot 5$ & $14 \cdot 8$ & 0.94 & $y=14 \cdot 8-20 \cdot 5 x$ \\
$\mathrm{~F}_{3}$ & $47 \cdot 0$ & 11.8 & 0.91 & $y=11 \cdot 8-47 \cdot 0 x$ \\
$\mathrm{~F}_{4}$ & $65 \cdot 0$ & 8.0 & 0.90 & $y=8 \cdot 0-65 \cdot 0 x$ \\
\hline
\end{tabular}

Enzyme assay was performed on microsomal fraction as described in 'Materials and Methods'.

The $K_{\mathrm{m}}$ and $V_{\max }$ values were estimated using Hofstee plots from data shown in Fig. 2.

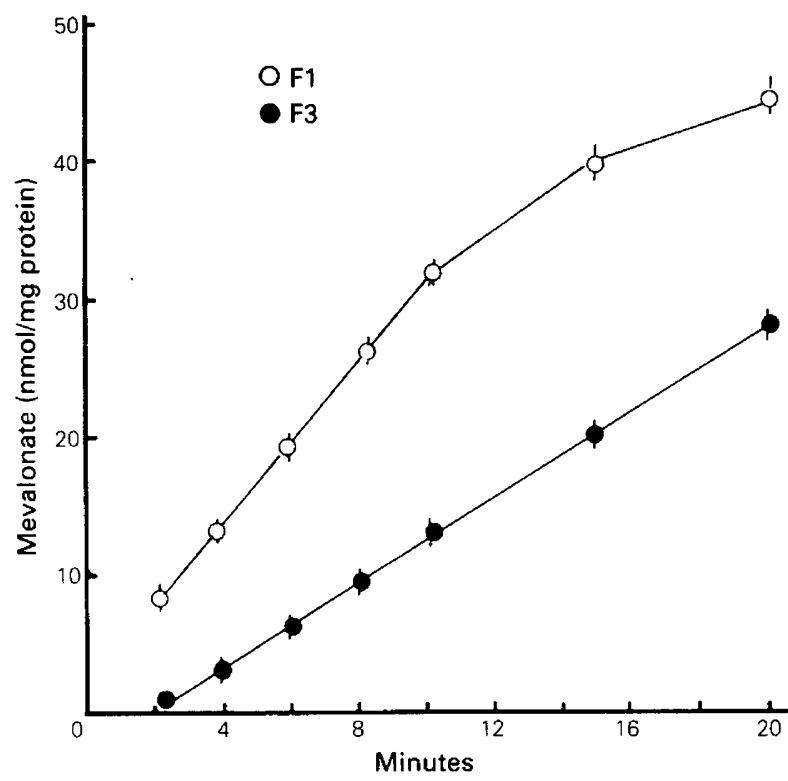

Fig. 4. Time course of HMG-CoA reductase activity. Microsomes obtained from granulosa membranes of follicles removed $2-3 \mathrm{~h}$ before ovulation were incubated with $10 \mu \mathrm{M}-\mathrm{HMG}-\mathrm{CoA}$. At the times indicated the reaction was stopped in some samples and treated as described in 'Materials and Methods'. Values presented are the mean \pm s.e.m. of triplicate incubations. The experiment was repeated and gave similar results.

\section{Discussion}

One of the significant findings of this study is the demonstration that HMG-CoA reductase activity increased with follicular development. Although there was a small increase in the apparent $V_{\max }$ with follicle size, the high specific activity of the enzyme in $F_{1}$ and $F_{2}$ follicles was due primarily to a $60-80 \%$ decrease in the apparent $K_{\mathrm{m}}$ as the follicles underwent maturation during the last few days of their lifespan. Ovarian HMG-CoA reductase activity has been shown to increase during pregnancy in rabbits (Kovanen et al., 1978) as well as in the ovary of the pseudopregnant rat (Schuler et al., 1979). The increase in enzyme activity under these conditions has been interpreted to reflect physiological responses of the ovary to increased demand of cholesterol for steroidogenesis. 
Progesterone, which plays a key role in the daily ovulatory cycle of the hen, is derived principally from the largest $\left(F_{1}\right)$ follicle (Etches et al., 1981). The ability of $F_{1}$ granulosa cells to respond to the preovulatory $\mathrm{LH}$ rise has been generally attributed (albeit by implication) to an increase in $\mathrm{LH}$ receptors and to the activity of $\mathrm{LH}$ receptor-coupled adenylate cyclase (Calvo et al., 1981). However, Asem \& Hertelendy (1985) have indicated that the activity of cholesterol side-chain cleavage enzyme (a critical step in the biosynthesis of progesterone from cholesterol), as well as that of the high $K_{\mathrm{m}} 3 \beta$-hydroxysteroid dehydrogenase, increases significantly during follicular maturation. Therefore, the ability of mature granulosa cells to produce progesterone can be attributed at least in part to such increments in the quantity of steroidogenic enzymes during the last few days of follicular development. In contrast, the present studies suggest that HMG-CoA reductase undergoes qualitative (decrease of $K_{\mathrm{m}}$ ) rather than quantitative changes during follicular maturation.

The fact that the granulosa cells of a single $F_{1}$ follicle are able to produce microgram quantities of progesterone per hour during short-term culture in response to appropriate stimulation, even in the absence of exogenous lipoprotein cholesterol (Asem \& Hertelendy, 1985) has suggested that large intracellular stores of cholesterol are present or active de-novo sterol synthesis takes place during such stimulation in combination with endogenous cholesterol mobilization.

The results obtained in the present studies do not permit distinction of these two possible events. However, Wells et al. (1981) have reported that, in fowl granulosa cells isolated in the late preovulatory period, progesterone production from endogenous precursors was over 60 times greater than that synthesized de novo from ${ }^{14} \mathrm{C}$-labelled substrates (acetate, octanoate, mevalonic acid lactone and glucose). Wells et al. (1981) concluded that cholesterol substrate utilized for progesterone synthesis in chicken granulosa cells in vitro did not originate from a newly synthesized pool. Preliminary studies (unpublished) in our laboratory seem to support the conclusion of Wells et al. (1981), because compactin in the dose range that inhibited HMG-CoA reductase activity had no significant effect on basal or LH-stimulated progesterone synthesis in vitro.

We thank Dr A. Endo, Tokyo Noko University, Tokyo, Japan, and Dr J. F. Strauss III, University of Pennsylvania, Philadelphia, PA, for the compactin; and Dr H. V. Biellier, University of Missouri, Columbia, MO, for the supply of experimental birds.

\section{References}

Asem, E.K. \& Hertelendy, F. (1985) Influence of follicular maturation on luteinizing hormone, cyclic $3^{\prime}$, $5^{\prime}$-adenosine monophosphate, forskolin and cholesterol stimulated progesterone production in hen granulosa cells. Biol. Reprod. 32, 257-268.

Balasubramanian, S., Goldstein, J.L., Faust, J.R., Brunschede, G.Y. \& Brown, M.S. (1977) Lipoprotein mediated regulation of 3-hydroxy-3-methylglutaryl coenzyme $\mathrm{A}$ reductase activity and cholesteryl ester metabolism in the adrenal gland of the rat. $\mathrm{J}$. biol. Chem. 252, 1770-1771.

Beg, Z.H. \& Brewer, B.H., Jr (1981) Regulation of liver 3-hydroxy-3-methylglutaryl-CoA reductase. Curr. Top. Cell. Reg. 20, 139-184.

Borkowski, A.J., Levin, S., Delcroix, D. \& Verhas, V. (1967) Blood cholesterol and hydrocortisone production in man: quantitative aspects of the utilization of circulating cholesterol by the adrenals at rest and under adrenocorticotropin stimulation. J. clin. Invest. 46, 797-806.

Bradford, M.M. (1976) A rapid and sensitive method for the quantitation of microgram quantities of protein utilizing the principle of protein-dye binding. Analyt. Biochem. 72, 248-254.

Calvo, F.O., Wang, S.-C. \& Bahr, J.M. (1981) LHstimulable adenylyl cyclase activity during the ovulatory cycle in granulosa cells of the three largest follicles and the postovulatory follicle of the domestic hen (Gallus domesticus). Biol. Reprod. 25, 805-812.

Endo, A., Tsujita, Y., Kuroda, M. \& Tanzawa, K. (1977) Inhibition of cholesterol synthesis in vitro and in vivo by KL-236A and ML-236B, competitive inhibitors of 3-hydroxy-3-methylglutaryl coenzyme $\mathrm{A}$ reductase. Eur. J. Biochem. 77, 31-36.

Etches, R.J., Croze, F. \& Duke, C.E. (1981) Plasma concentrations of luteinizing hormone, progesterone, testosterone and estradiol in follicular and venous plasma during the ovulation cycle of the hen. In Recent Advances in Avian Endocrinology. Advances in Physiological Sciences, vol. 33, pp. 89-98. Eds G. Pethes, P. Peczely \& P. Rudas. Pergamon, New York. Gwynne, J.T. \& Strauss, J.F., III (1982) The role of 
lipoproteins in steroidogenesis and cholesterol metabolism in steroidogenic glands. Endocr. Rev. 3, 299-329.

Hammond, R.W., Olson, D.M., Frenkel, R.B., Biellier, H.V. \& Hertelendy, F. (1980) Prostaglandins and steroid hormones in plasma and ovarian follicles during the ovulation cycle of the domestic hen (Gallus domesticus). Gen. comp. Endocr. 42, 195-202.

Hellig, H., Gottereau, D., Lefebvre, Y. \& Bolté, E. (1970) Steroid production from plasma cholesterol. 1 , Conversion of plasma cholesterol to placental progesterone in humans. J. clin. Endocr. Metab. 30, 624-631.

Hertelendy, F. \& Asem, E.K. (1984) Steroidogenesis in granulosa cells during follicular maturation: evidence for desensitization and resensitization during the ovulation cycle. J. exp. Zool. 232, 513-520.

Hofstee, B.H.J. (1952) On the evaluation of the constants $V_{\max }$ and $K_{\mathrm{m}}$ in enzyme reactions. Science, N.Y. 116, 329-331.

Kovanen, P.T., Goldstein, J.L. \& Brown, M.S. (1978) High levels of 3-hydroxy-3-methylglutaryl coenzyme A reductase activity and cholesterol synthesis in the ovary of the pregnant rabbit. J. biol. Chem. 253, 5126-5132.

Krum, A.A., Morris, M.D. \& Bennett, L.L. (1964) Role of cholesterol in the in vivo biosynthesis of adrenal steroids by the dog. Endocrinology 74, 543-549.
Lehoux, J.-G. \& Lefebvre, A. (1980) De novo synthesis of corticoids in hamster adrenal glands. J. Steroid Biochem. 12, 479-485.

Major, P.W., Armstrong, D.T. \& Greep, R.O. (1967) Effects of luteinizing hormone in vivo and in vitro on cholesterol conversion to progestins in rat corpus luteal tissue. Endocrinology 81, 19-27.

Morris, M.D. \& Chaikoff, I.L. (1959) The origin of cholesterol in liver, small intestine, adrenal gland and testis of the rat: dietary versus endogenous contributions. J. biol. Chem. 234, 1095-1102.

Schuler, L.A., Scavo, L., Kirsch, T.M., Flickinger, G.L. \& Strauss, J.F., III (1979) Regulation of de novo biosynthesis of cholesterol and progestins, and formation of cholesteryl ester in rat corpus luteum by exogenous sterol. J. biol. Chem. 254, 8662-8668.

Silavin, S.L. \& Strauss, J.F., III (1983) Progesterone production by hamster granulosa and luteal cells during short term incubation. Effects of lipoproteins, compactin and 25-hydroxycholesterol. Biol. Reprod. 29, 1163-1171.

Wells, J.W., Dick, H.R. \& Gilbert, A.B. (1981) The biosynthesis of progesterone by fowl granulosa cells in vitro from ${ }^{14} \mathrm{C}$-labelled substrates. $J$. Steroid Biochem. 14, 651-656.

Received 20 May 1986 